\title{
C-reactive protein and clinical subtypes of major depressive disorder at Zagazig University Hospitals
}

\author{
Amany Elshabrawy Mohamed ${ }^{*}$, Rafik Reda Abd El-Latif ${ }^{\dagger}$, Amira Mohamed Youssef ${ }^{\dagger}$ and Abdallah Saad Ibrahim ${ }^{\dagger}$
}

\begin{abstract}
Background: Although, the relation between inflammation and major depressive disorder (MDD) looks like firm, it may not exist in all patients with depression. Therefore, the main aim of this study was to compare serum Creactive protein (CRP) level among clinical subtypes of MDD and its relation with suicidality.

Results: According to the Diagnostic and Statistical Manual of Mental Disorders, Fifth Edition (DSM-5) criteria for MDD, 98 patients included and categorized into five clinical subtypes groups: atypical, anxious, melancholic, psychotic, and unspecified depression with percent $(11.2 \%, 31.6 \%, 19.4 \%, 15.3 \%$, and $22.4 \%)$ respectively. Twentyfour (24.5\%) of all patients had suicidal thoughts using Beck Scale for Suicidal Ideation (BSS) with statistically significant increase $\left(P<0.05^{*}\right)$ in suicidality among atypical group. On assessing CRP level, there was highly statistical significant increase $\left(P<0.001^{* *}\right)$ among cases with atypical type and also cases with suicidal ideation. Also, logistic regression analysis found that the significant predictors for high CRP among the studied cases were smoking, suicidality, atypical depression, and suicide depression.
\end{abstract}

Conclusions: Higher level of CRP was found among patients with atypical MDD, and there was significant relationship between CRP and suicidality.

Keywords: C-reactive protein, Depression subtypes, Suicidality

\section{Background}

Recently, there is increased attention for contribution of inflammation in mental illness [1]. Patients with neuropsychiatric disorders hold cardinal features of inflammation, involving raised inflammatory mediators targeting all tissues, which may contribute to the pathophysiology and clinical progression of these disorders. Pro-inflammatory cytokines modulate cognition and mood behavior by decreasing levels of brain monoamine, stimulating neuroendocrine responses, and impairing brain plasticity [2].

$\mathrm{C}$-reactive protein (CRP) that is plasma protein and synthesized by hepatocytes increases due to infection or tissue injury. It is a suitable marker for systemic inflammation

\footnotetext{
* Correspondence: Ahmed2001go@yahoo.com

${ }^{+}$Rafik Reda Abd El-Latif, Amira Mohamed Yousef and Abdallah Saad Ibrahim contributed equally to this work.

Faculty of Medicine, Zagazig University, Zagazig, Egypt
}

because it is available, cheap, relatively stable in stored specimens, and not influenced by day time or meal intake [3].

The inflammatory hypothesis role in major depressive disorder (MDD) has been stated many times and evidenced by elevated levels of acute phase reactants and pro-inflammatory cytokines [4].

Even though the relation between inflammation and MDD looks like firm, they may not exist in all depression cases. MDD diagnosis is highly heterogeneous, and there is various depression subtypes. It is recognized that the heterogeneity of depression is impeding the identification of depression biomarkers, as different subtypes may be the result of several pathophysiological mechanisms [5].

MDD divided into psychotic, atypical, melancholic, and anxious depression. Subtyping depression is a promising effort to overcome the non-specificity of different diagnostic constructs like major depression [6].

\section{Springer Open}

(c) The Author(s). 2020 Open Access This article is licensed under a Creative Commons Attribution 4.0 International License, which permits use, sharing, adaptation, distribution and reproduction in any medium or format, as long as you give appropriate credit to the original author(s) and the source, provide a link to the Creative Commons licence, and indicate if changes were made. The images or other third party material in this article are included in the article's Creative Commons licence, unless indicated otherwise in a credit line to the material. If material is not included in the article's Creative Commons licence and your intended use is not permitted by statutory regulation or exceeds the permitted use, you will need to obtain permission directly from the copyright holder. To view a copy of this licence, visit http://creativecommons.org/licenses/by/4.0/. 
Previously, some evidence has indeed been found for differential relationship between inflammation and depression subtypes [7]. Multiple studies reported that CRP was higher among patients with atypical depression versus melancholic depression patients and controls [8].

Higher levels of CRP were associated with increased severity of depression symptoms and suicidality [9]. Depressed patients with high suicidal ideation had higher CRP levels than patients with low suicidal ideation and healthy controls [10].

So, this study aimed to compare serum CRP level among clinical subtypes of MDD and its relation with suicidality.

\section{Methods}

\section{Study design and setting}

A cross sectional study was done in inpatient wards and outpatient clinic of the Psychiatry Department, Zagazig University hospitals, during the period from 15 January 2019 till 15 July 2019.

\section{Study participants}

Eligibility of patients for participation in this study was determined according to the specified inclusion and exclusion criteria:

\section{Inclusion criteria}

- All patients should meet the Diagnostic and Statistical Manual of Mental Disorders, Fifth Edition (DSM-5) criteria for MDD [11].

- Patients have not taken any antidepressant for the present episode.

- Age ranging from 18 to 60 years old.

- Both sexes were included.

- Different social classes were included.

\section{Exclusion criteria}

- Patients took antidepressant within 6 months before the study.

- History of manic or hypo manic episodes in patients and first degree relatives.

- Patients with any infection, trauma due to surgery, fractures, or burns within 1 month prior to the study.

- Patients with inflammatory disease, malignancies, medication affecting CRP, or substance abuse.

- Pregnant women or pregnant within 6 months before the study.

- Females using oral contraceptive pills within 6 months prior to the study.

\section{Sampling}

Assuming the population size (attendance rate of patients with MDD in 6 months) was 2562, with life time prevalence of MDD is about $4.7 \%$ worldwide, power of the test $85 \%$, and confidence interval (CI) $95 \%$, the sample was 70 , and non-response rate $40 \%$ was added, so the sample was 98 patients with MDD. The selection was performed by simple and systematic random sampling techniques from inpatient wards and outpatient clinic of the Psychiatry Department respectively. The simple random selection was done by lottery, and systematic random technique was carried out as the mean attendance of patients that was eight patients/day, so each 4th patient was chosen in the sample. Because patients might attend for follow-up, if the patient was repeated, the next patient would be chosen instead of her/him.

\section{Tools and operational steps}

All included patients were subjected to:

A semi-structured interview derived from the Zagazig psychiatric sheet to collect the following data (age, sex, marital state, education, residence, occupation, body mass index (BMI), and smoking.

Psychometric assessment was done by:

Structured Clinical Interview for DSM-V (SCID): to apply the diagnostic criteria for MDD and to categorize patients into five groups (atypical, anxious, melancholic, psychotic, and unspecified). The SCID5 is organized into diagnostic modules, and it assesses mood disorders, psychotic disorders, substance use disorders, anxiety disorders, obsessive-compulsive and related disorders, eating disorders, somatic symptom disorders, some sleep disorders, "externalizing disorders", and trauma and stressorrelated disorders. It has been published in various forms, including a version for clinicians (SCID-CV) and a version for clinical trials (SCID-CT) [11].

Beck Scale for Suicidal Ideation (BSS): which is a selfreport scale included 19 items with total score range from 0 to 48 . No specific cutoff exists to classify severity; however, increasing scores reflect greater suicide risk [12]. Cutoff $\geq 24$ was used in the current study [13]. The translated Arabic version which was used in this study was also used in a previous study [14].

\section{Laboratory assessment}

Blood sampling and CRP measurements Blood samples $(5 \mathrm{~mL})$ in anticoagulant free aliquot for each participant were collected by venipuncture. Complete clot formation had taken place before centrifugation [15]. Serum samples were then stored at $-80{ }^{\circ} \mathrm{C}$ until the day of analysis. Measurements were performed with the Roche/COBAS INTEGRA system 400, C-reactive protein (latex) high sensitive assay (Roche Diagnostics), a latex particle-enhanced immunoturbidimetric method, with a measurement range of 1.0 to $200 \mathrm{mg} / \mathrm{L}$. 


\section{Statistical analysis}

The collected data were coded, entered, and analyzed using Statistical Package for Social Science (SPSS) version 25. Qualitative variables were expressed as a number and percent, and quantitative data were expressed as mean \pm standard deviation (SD) median with range (for not normally distributed data). I-squared test $\left(\chi^{2}\right)$ was used to detect the relation between different qualitative variables. For quantitative variables, One-way ANOVA test ( $F$ test) was used as appropriate for normally distributed data while non-parametric data was evaluated with KruskalWallis test (KW) and Mann-Whitney $U$ test (MW). The results were considered statistically significant and highly statistical significant when the significant probability $(P$ value) was $<0.05^{*}$ and $<0.001^{* * *}$ respectively.

\section{Results}

Demographic and clinical assessment

The study at hand included 98 patients with MDD who were divided into five groups: atypical, anxious, melancholic, psychotic, and unspecified MDD.

These groups included 11 (11.2\%), 31 (31.6\%), 19 (19.4\%), 15 (15.3\%), and $22(22.4 \%)$ patients respectively. There was no statistically significant difference between the five subtypes groups regarding all demographic and clinical characteristics except for age, sex, and education $\left(P<0.05^{*}\right)$ where higher mean age $(45.6 \pm 11.38$ years $)$ was found among psychotic subtype, atypical depression (90.9\%) was more common among female, and high school education was higher among unspecified type (54.5\%) (Table 1).

Table 1 Demographic and clinical characteristics of the five MDD subtypes groups $(n=98)$

\begin{tabular}{|c|c|c|c|c|c|c|c|c|c|c|c|c|}
\hline \multirow{2}{*}{$\begin{array}{l}\text { Variable } \\
\text { Age: (years) }\end{array}$} & \multicolumn{2}{|c|}{$\begin{array}{l}\text { Atypical }(\boldsymbol{n}=11) \\
11.2 \%\end{array}$} & \multicolumn{2}{|c|}{$\begin{array}{l}\text { Anxious }(\boldsymbol{n}=31) \\
31.6 \%\end{array}$} & \multicolumn{2}{|c|}{$\begin{array}{l}\text { Melancholic }(\boldsymbol{n}=19) \\
19.4 \%\end{array}$} & \multicolumn{2}{|c|}{$\begin{array}{l}\text { Psychotic }(\boldsymbol{n}=15) \\
15.3 \%\end{array}$} & \multicolumn{2}{|c|}{$\begin{array}{l}\text { Unspecified }(\boldsymbol{n}=22) \\
22.4 \%\end{array}$} & \multirow[t]{2}{*}{$f$} & \multirow[t]{2}{*}{$P$} \\
\hline & & & & & & & & & & & & \\
\hline Mean \pm SD & \multicolumn{2}{|c|}{$35.7 \pm 11.06$} & \multicolumn{2}{|c|}{$36.5 \pm 10.4$} & \multicolumn{2}{|c|}{$42.9 \pm 10.9$} & \multicolumn{2}{|c|}{$45.6 \pm 11.38$} & \multicolumn{2}{|c|}{$35.4 \pm 12.66$} & \multirow[t]{2}{*}{2.85} & \multirow[t]{2}{*}{$0.03^{*}$} \\
\hline Range & \multicolumn{2}{|c|}{$20-58$} & \multicolumn{2}{|c|}{$19-60$} & \multicolumn{2}{|c|}{$19-57$} & \multicolumn{2}{|c|}{$18-57$} & \multicolumn{2}{|c|}{$18-59$} & & \\
\hline \multicolumn{13}{|l|}{ BMI: $\left(\mathrm{Kg} / \mathrm{m}^{2}\right)$} \\
\hline Mean \pm SD & \multicolumn{2}{|c|}{$29.33 \pm 3.98$} & \multicolumn{2}{|c|}{$29.06 \pm 3.42$} & \multicolumn{2}{|c|}{$30.8 \pm 4.56$} & \multicolumn{2}{|c|}{$30.36 \pm 3.19$} & \multicolumn{2}{|c|}{$30.03 \pm 2.99$} & \multirow[t]{2}{*}{0.77} & \multirow[t]{2}{*}{$0.54 \mathrm{NS}$} \\
\hline Range & $21-35$ & & $23-3$ & & $22-4$ & & 22.8 & & $26-3$ & & & \\
\hline Variable & No. & $\%$ & No. & $\%$ & No. & $\%$ & No. & $\%$ & No. & $\%$ & $x^{2}$ & $P$ \\
\hline Sex & & & & & & & & & & & & \\
\hline Male & 1 & 9.1 & 8 & 25.8 & 9 & 47.4 & 9 & 60 & 7 & 31.8 & 9.93 & $0.04 *$ \\
\hline Female & 10 & 90.9 & 23 & 74.2 & 10 & 52.6 & 6 & 40 & 15 & 68.2 & & \\
\hline Marital status & & & & & & & & & & & & \\
\hline Single & 3 & 27.3 & 6 & 19.3 & 3 & 15.8 & 3 & 20 & 5 & 22.7 & 5.88 & $0.92 \mathrm{NS}$ \\
\hline Married & 6 & 54.5 & 20 & 64.5 & 10 & 52.6 & 9 & 60 & 14 & 63.6 & & \\
\hline Widow & 1 & 9.1 & 4 & 13 & 2 & 10.5 & 1 & 6.7 & 1 & 4.5 & & \\
\hline Divorced & 1 & 9.1 & 1 & 3.2 & 4 & 21.1 & 2 & 13.3 & 2 & 9.1 & & \\
\hline Education & & & & & & & & & & & & \\
\hline Illiterate & 1 & 9.1 & 7 & 22.6 & 3 & 15.8 & 1 & 6.7 & 1 & 4.5 & 22.2 & $0.03^{*}$ \\
\hline Basic & 5 & 45.5 & 8 & 25.8 & 8 & 42.1 & 5 & 33.3 & 8 & 36.4 & & \\
\hline High school & 1 & 9.1 & 12 & 38.7 & 7 & 36.8 & 3 & 20 & 12 & 54.5 & & \\
\hline College & 4 & 36.3 & 4 & 13 & 1 & 5.3 & 6 & 40 & 1 & 4.5 & & \\
\hline Occupation & & & & & & & & & & & & \\
\hline Working & 2 & 18.2 & 15 & 48.4 & 11 & 57.9 & 10 & 66.7 & 7 & 31.8 & 8.94 & $0.06 \mathrm{NS}$ \\
\hline Not Working & 9 & 81.8 & 16 & 51.6 & 8 & 42.1 & 5 & 33.3 & 15 & 68.2 & & \\
\hline Residence & & & & & & & & & & & & \\
\hline Urban & 5 & 45.5 & 8 & 25.8 & 7 & 36.8 & 6 & 40 & 6 & 27.3 & 2.28 & $0.68 \mathrm{NS}$ \\
\hline Rural & 6 & 54.5 & 23 & 74.2 & 12 & 63.2 & 9 & 60 & 16 & 72.7 & & \\
\hline Smoking & & & & & & & & & & & & \\
\hline Yes & 1 & 9.1 & 7 & 22.6 & 7 & 36.8 & 5 & 33.3 & 5 & 22.7 & 3.55 & $0.47 N S$ \\
\hline No & 10 & 90.9 & 24 & 77.4 & 12 & 63.2 & 10 & 66.7 & 17 & 77.3 & & \\
\hline
\end{tabular}




\section{Psychometric assessment}

We assessed suicidal ideation by BSS, and the mean beck suicide was 8.73 with a range from 0 to 37 . Also, 24 (24.5\%) patients diagnosed to have suicidal thoughts (Table 2).

On comparing the five studied groups regarding suicidal ideation, there was statistically significant increase $\left(P<0.05^{*}\right)$ in suicidality among atypical MDD with mean score $9.17 \pm 2.33$, while the mean scores among other groups (anxious, melancholic, psychotic, and unspecified) were $(3.32 \pm 3.74,3.24 \pm 3.6,3.77 \pm 2.93$, and $4.05 \pm 5.5$ ) respectively (Table 3 ).

\section{Laboratory assessment (CRP)}

CRP level among the five MDD groups shows that there was highly statistical significant higher $(P<0.001 * *)$ CRP level in cases with atypical depression compared to other types (Table 4).

Also, on studying the relation between suicidality and CRP levels, highly statistical significant increase $(P<$ $0.001 * \%)$ in CRP level was found among patients with suicidal ideation with mean level $7.13 \pm 4.14$ and range 0.31-15.67 (Table 5).

\section{Finally}

After performing logistic regression analysis for significant factors of high CRP among the studied cases, we found that the significant predictors for high CRP were smoking, suicidality, atypical depression, and suicide depression (Table 6).

\section{Discussion}

The divergent nature of depression makes its clinical features alone not sufficient to guide precise decision-making regarding medications or prevention of relapse. Therefore, biomarkers are needed to facilitate characterization of MDD subtypes and decisions on effective individualized therapy [16].

Our study at hand was the first one to compare between the five clinical subtypes of MDD regarding CRP levels in the chosen place. In our study, ninety-eight

Table 2 Beck suicide score among the studied patients $(n=98)$

\begin{tabular}{lll}
\hline Variable & Value & \\
\hline Beck suicide & & \\
Mean \pm SD & $8.73 \pm 12.83$ & \\
Median & 0 & \\
Range & $0-37$ & $\%$ \\
Suicidal ideation & No. & 75.5 \\
No & 74 & 24.5 \\
Yes & 24 &
\end{tabular}

$S D$ standard deviation
Table 3 Suicidal ideation among the five MDD subtypes groups $(n=98)$

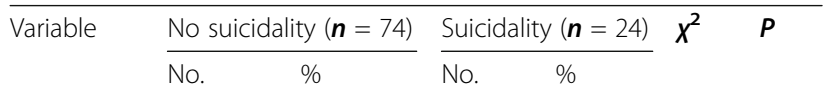

Type of depression

\begin{tabular}{lllllll} 
Atypical & 4 & 5.4 & 7 & 29.2 & 12.45 & $\mathbf{0 . 0 1 *}$ \\
Anxious & 26 & 35.1 & 5 & 20.8 & & \\
Melancholic & 15 & 20.3 & 4 & 16.7 & & \\
Psychotic & 10 & 13.5 & 5 & 20.8 & & \\
Unspecified & 19 & 25.7 & 3 & 12.5 & & \\
\hline
\end{tabular}

$M D D$ major depressive disorder, $\chi^{2}$ chi-square test

*Significant $(P<0.05)$

patients with DSM-5 diagnosis of MDD included and divided into five groups: atypical, anxious, melancholic, psychotic, and unspecified MDD. We found that there was highly statistical significance increase in CRP level among cases with atypical depression when compared to other types. Moreover, logistic regression analysis for high CRP among the studied cases found that the significant predictors were suicidality and atypical depression, which further support our results.

In consistence with our study, a large sample based studies in which CRP found to be higher in atypical depression versus melancholic type $[8,17]$ and versus nonatypical and unspecific MDD $[8,18]$.

On the other hand, Karlović et al. mentioned that there was no difference between melancholic and atypical depression cases regarding CRP level [19] and also, Bai et al. noted that no CRP difference was found between atypical, melancholic, and unspecified groups [20]. In addition, another study conducted by Rothermundt et al. in which no difference was found between nonmelancholic depression and melancholic cases as regard CRP level [21]. Other studies observed that there was no difference in the levels of inflammatory cytokines between MDD subtypes [22, 23]. Jha et al. reported that patients with atypical features had lower CRP levels than those without atypical features [3].

Table 4 CRP levels among the five MDD subtypes groups $(n=98)$

\begin{tabular}{|c|c|c|c|c|c|c|c|}
\hline \multirow[t]{2}{*}{ Variable } & \multirow[t]{2}{*}{ No. } & \multicolumn{4}{|l|}{ CRP } & \multirow[t]{2}{*}{$K$} & \multirow[t]{2}{*}{$P$} \\
\hline & & Mean & SD & Median & Range & & \\
\hline \multicolumn{8}{|c|}{ Type of depression } \\
\hline Atypical & 11 & 9.17 & 2.33 & 8.85 & $5.7-14.69$ & 18.22 & $0.001^{* *}$ \\
\hline Anxious & 31 & 3.32 & 3.74 & 1.85 & $0.21-15.67$ & & \\
\hline Melancholic & 19 & 3.24 & 3.61 & 1.52 & $0.34-14.7$ & & \\
\hline Psychotic & 15 & 3.77 & 2.93 & 2.01 & $0.31-9.04$ & & \\
\hline Unspecified & 22 & 4.05 & 5.5 & 1.4 & $0.21-22.63$ & & \\
\hline
\end{tabular}

CRP C-reactive protein, $M D D$ major depressive disorder, $S D$ standard deviation, $K$ Kruskal-Wallis test

**Highly significant $(P<0.001)$ 
Table 5 Relation between suicidality and CRP levels $(n=98)$

\begin{tabular}{|c|c|c|c|c|c|c|c|}
\hline \multirow[t]{2}{*}{ Variable } & \multirow[t]{2}{*}{ No. } & \multicolumn{4}{|l|}{ CRP } & \multirow[t]{2}{*}{ MW } & \multirow[t]{2}{*}{$P$} \\
\hline & & Mean & SD & Median & Range & & \\
\hline \multicolumn{8}{|c|}{ Suicidal ideation } \\
\hline Yes & 24 & 7.13 & 4.14 & 8.32 & $0.31-15.67$ & 3.85 & $<0.001 * *$ \\
\hline No & 74 & 3.24 & 3.90 & 1.78 & $0.21-22.63$ & & \\
\hline
\end{tabular}

CRP C-reactive protein, $S D$ standard deviation, $M W$ Mann-Whitney test

${ }^{*}$ Highly significant $(P<0.001)$

It is important to know that not all researches that study the link between inflammation and depression detect increase levels of inflammatory cytokines or detect different elevated cytokines [24, 25], this discrepancy is due to heterogeneity of MDD, and the fact that inflammatory processes did not play the same causal role in different subtypes of depression [26, 27].

A study includes 1367 patient with major depressive disorders and its subtypes (atypical, melancholic, combined atypical and melancholic, and unspecified), CRP was measured at baseline and after follow-up for 5 years, and combined subtype was found to be associated with increased level of CRP at baseline, while atypical subtype was associated with increased CRP level at baseline and also after follow-up [8].

However, other studies reported that there are no differences in levels of inflammatory cytokines between different subtypes of MDD [22, 23]

Studies had found that inflammation plays a greater role in the pathogenesis of atypical depression, and inflammatory cytokines were found to be elevated in atypical depression compared with other subtypes of $\operatorname{MDD}[18,28,29]$.

One explanation could be that $18-36 \%$ of patients with major depressive disorder are classified as atypically depressed, with more prevalence in female [30, 31]. Bowlby's attachment theory concludes that early rejection in childhood leads to interpersonal sensitivity in later life [32]. Many studies found that patients with atypical MDD had history of childhood maltreatment more than other subtypes of MDD [30, 33]. Interestingly, a study found that inflammatory markers including both white blood cell count and CRP is elevated in victims of childhood trauma independently of exposing to psychosocial stressors during adulthood [34].

Another explanation is that patients with atypical depression had a higher body mass index (BMI) compared with patients with melancholic depression [31], and it is known that adipose tissue is considered a reserve of cytokines [35, 36], so inflammatory cytokines involving CRP, IL- 6 , and TNF- $\alpha$ are found to be elevated in atypical depression than melancholic depression [18].

Atypical depression had a higher prevalence with chronic fatigue and fibromyalgia [37], and all are characterized by inflammatory processes [38].

It is worth to mention that since many studies had evident in the great role of neuroinflammation in atypical subtype of MDD, it would make sense that patients with atypical depression would benefit more from an antiinflammatory treatment [37].

We assessed suicidal ideation by BSS and found that (24.5\%) of patients had suicidal thoughts.

On comparing suicidality among the five included groups, statistically significant increase in suicidal ideation was found among the atypical group. Similarly, Xin et al. concluded that patients with atypical MDD had more suicidality than other types [39]. In contrast, the study carried out by McIntyre et al. who found that suicidality was higher among patients with anxious depression. This disparity may be attributed to different sample size, severity degree, illness duration, functional impairment, and number of episodes among patients with MDD subtypes [17].

Regarding CRP level and suicidality, the present study found that there was highly statistical significant relationship between CRP and suicidality. In a study included 600 patients with MDD, elevated CRP levels were found to be associated with history of suicidal attempts, and this association remained significant even after exclusion of patients with chronic diseases [40]. Also, Suchankova et al. mentioned that specific alleles in the gene of CRP are more common among depressed patients with history of suicide attempt [41].

Table 6 Logistic regression analysis for significant factors of high CRP among the studied patients $(n=98)$

\begin{tabular}{|c|c|c|c|c|c|c|c|}
\hline \multirow[t]{2}{*}{ Variables } & \multirow[t]{2}{*}{$B$} & \multirow[t]{2}{*}{ S.E. } & \multirow[t]{2}{*}{ Wald } & \multirow[t]{2}{*}{$\boldsymbol{P}$ value } & \multirow[t]{2}{*}{ OR } & \multicolumn{2}{|l|}{$95 \% \mathrm{Cl}$} \\
\hline & & & & & & Lower & Upper \\
\hline Female sex & 0.13 & 0.12 & 0.45 & 0.32 & 1.01 & 0.86 & 2.35 \\
\hline Smoker & 1.02 & 0.59 & 1.23 & $0.04^{*}$ & 2.01 & 1.26 & 5.62 \\
\hline Suicidality & 1.04 & 0.62 & 1.94 & $0.03^{*}$ & 2.34 & 1.07 & 4.93 \\
\hline Atypical depression & 1.18 & 0.68 & 3.13 & $0.002^{*}$ & 3.95 & 2.12 & 8.20 \\
\hline High BMI & -0.04 & 0.06 & 0.65 & 0.48 & 1.23 & 0.97 & 1.97 \\
\hline Suicide depression by Beck & 1.03 & 0.60 & 1.91 & $0.04^{*}$ & 2.16 & 1.02 & 3.45 \\
\hline
\end{tabular}

$B M I$ body mass index, $S E$ standard error, $O R$ odds ratio, $C I$ confidence interval

*Significant $(P<0.05)$ 
The abovementioned result further supported by the study of Köhler-Forsberg et al. [9] and O'Donovan et al. [10] in which higher CRP levels were significantly related with suicidality among cases with MDD.

However, karlović et al. [19] and Vargas et al. [42] reported that there was no significant difference in CRP level between suicidal and non-suicidal depressed patients. This variation could be clarified by differences in sample size, sex, smoking, BMI, severity of illness, and antidepressants usage which greatly affect CRP levels.

This study had some limitations: the relatively small sample size, the data cannot be generalized as all patients were taken from the same place, and other clinical data affecting CRP as age of disease onset, duration of illness, and family history that were not included.

\section{Conclusions}

The study at hand concluded that patients with atypical MDD had higher level of CRP than other subtypes, and significant relationship was found between CRP level and suicidality. Also, it was showed that atypical subtype with psychotic depression had more suicidal ideation. We recommend that further studies with large sample sizes and adjustment of variables affecting CRP level are required.

\section{Abbreviations \\ BMI: Body mass index; BSS: Beck Scale for Suicidal Ideation; Cl: Confidence interval; CRP: C-reactive protein; DSM-5: Diagnostic and Statistical Manual of Mental Disorders, Fifth Edition; F test: One-way ANOVA test; KW: Kruskal- Wallis test; MDD: Major depressive disorder; MW: Mann-Whitney $U$ test; SCID: Structured Clinical Interview for DSM-V; SD: Standard deviation; SPSS: Statistical Package for Social Science; $X^{2}$ : Chi-square test}

\section{Acknowledgements}

The authors would like to thank all the study participants.

\section{Authors' contributions}

AE designs the work and shared in drafting of the article.

RA performed acquisition of data and shared in the drafting of the article. AY drafts the article and substantively revised it. Al performed the analysis, interpretation of data, and shared in the drafting of the article. All authors have read and approved the final manuscript.

\section{Funding}

The authors declare that they have no funding support.

\section{Availability of data and materials}

Not applicable.

\section{Ethics approval and consent to participate}

- An official permission was obtained from the Institutional Review Board at Faculty of Medicine, Zagazig University hospitals (ZU-IRB\#5081/25-12-2018).

- An official permission was obtained from the Psychiatry Department at the same University.

- A written informed consent was obtained from the participants, after clarifying of the aim of the study, methods, and duration of the study.

- Study participants had the right to withdraw from the study at any time and without negatively affecting their medical care.

- The results of this study could be used as a scientific publication but the identity of the participant will be absolutely confidential.

\section{Consent for publication}

A written informed consent was voluntarily sought from the participants.

\section{Competing interests}

The authors declare that they have no competing interests.

Received: 11 January 2020 Accepted: 2 June 2020

Published online: 27 July 2020

\section{References}

1. Faugere M, Micoulaud-Franchi JA, Faget-Agius C, Lançon C, Cermolacce M, Richieri R (2018) High C-reactive protein levels are associated with depressive symptoms in schizophrenia. J Affect Disord 225:671-675

2. Bauer ME, Teixeira AL (2019) Inflammation in psychiatric disorders: what comes first? Ann N Y Acad Sci 1437(1):57-67

3. Jha MK, Minhajuddin A, Gadad BS, Greer T, Grannemann B, Soyombo A et al (2017) Can C-reactive protein inform antidepressant medication selection in depressed outpatients? Findings from the CO-MED trial.

Psychoneuroendocrinology 78:105-113

4. Gardner A, Boles RG (2011) Beyond the serotonin hypothesis: mitochondria, inflammation and neurodegeneration in major depression and affective spectrum disorders. Prog Neuropsychopharmacol Biol Psychiatry 35(3):730743

5. Antonijevic IA (2006) Depressive disorders - is it time to endorse different pathophysiologies? Psychoneuroendocrinology 31(1):1-15

6. Baumeister H, Parker G (2012) Meta-review of depressive subtyping models. J Affect Disord 139(2):126-140

7. Baune BT, Stuart M, Gilmour A, Wersching H, Heindel W, Arolt V et al (2012) The relationship between subtypes of depression and cardiovascular disease: a systematic review of biological models. Translational Psychiatry 2(3):e92

8. Glaus J, Vandeleur CL, von Känel R, Lasserre AM, Strippoli MPF, GholamRezaee $\mathrm{M}$ et al (2014) Associations between mood, anxiety or substance use disorders and inflammatory markers after adjustment for multiple covariates in a population-based study. J Psychiatr Res 58:36-45

9. Köhler-Forsberg O, Buttenschøn HN, Tansey KE, Maier W, Hauser J, Dernovsek MZ (2017) Association between C-reactive protein (CRP) with depression symptom severity and specific depressive symptoms in major depression. Brain Behav Immun 62:344-350

10. O'Donovan A, Rush G, Hoatam G, Hughes BM, McCrohan A, Kelleher C et al (2013) Suicidal ideation is associated with elevated inflammation in patients with major depressive disorder. Depress Anxiety 30(4):307-314

11. Wootton BM, Worden BL, Norberg MM, Grisham JR, Steketee G (2019) A clinician's quick guide to evidence-based approaches: hoarding disorder. Clin Psychol 23(1):85-87

12. Beck AT, Steer RA, Ranieri WF (1988) Scale for suicide ideation: psychometric properties of a self-report version. J Clin Psychol 44(4):499-505

13. Cochrane-Brink KA, Lofchy JS, Sakinofsky I (2000) Clinical rating scales in suicide risk assessment. Gen Hospital Psych 22(6):445-451

14. Alsalman R (2016) Gender differences in suicide ideation among college students in Kuwait. European Psychiatry 33:S746

15. Clinical and laboratory Standards Institute (2004): NCCLS procedures for the handling and processing of blood specimens; Approved guideline-third edition. USA.

16. Schmidt HD, Shelton RC, Duman RC, Functional biomarker in depression : diagnosis, treatment and pathophysiology .Neuropsychopharmacology. 2011;36912):2375-94

17. McIntyre RS, Lee Y, Zhou AJ, Rosenblat JD, Peters EM, Lam RW et al (2017) The efficacy of psychostimulants in major depressive episodes: a systematic review and meta-analysis. J Clin Psychopharmacol 37(4):412-418

18. Lamers F, Vogelzangs N, Merikangas KR, De Jonge $P$, Beekman ATF, Penninx BWJH (2013) Evidence for a differential role of HPA-axis function, inflammation and metabolic syndrome in melancholic versus atypical depression. Mol Psychiatry 18(6):692-699

19. Karlović D, Serretti A, Vrkić N, Martinac M, Marčinko D (2012) Serum concentrations of CRP, IL-6, TNF- $a$ and cortisol in major depressive disorder with melancholic or atypical features. Psychiatry Res 198(1):74-80

20. Bai YM, Su TP, Li CT, Tsai SJ, Chen MH, Tu PC et al (2015) Comparison of pro-inflammatory cytokines among patients with bipolar disorder and unipolar depression and normal controls. Bipolar Disorders 17(3):269-277 
21. Rothermundt M, Arolt V, Fenker J, Gutbrodt H, Peters M, Kirchner H (2001) Different immune patterns in melancholic and non-melancholic major depression. Eur Arch Psychiatry Clin Neurosci 251(2):90-97

22. Dunjic-Kostic B, Ivkovic M, Radonjic NV, Petronijevic ND, Pantovic M, Damjanovic A et al (2013) Melancholic and atypical major depression-connection between cytokines, psychopathology and treatment. Prog Neuropsychopharmacol Biol Psychiatry 43:1-6

23. Euteneuer F, Dannehl K, del Rey A, Engler H, Schedlowski M, Rief W (2017) Peripheral immune alterations in major depression: the role of subtypes and pathogenetic characteristics. Front Psychiatry 8:250

24. Valkanova V, Ebmeier KP, Allan CL (2013) CRP, IL-6 and depression: a systematic review and meta-analysis of longitudinal studies. J Affect Disord 150(3):736-744

25. Hestad KA, Engedal K, Whist JE, Aukrust P, Farup PG, Mollnes TE, Ueland T (2016) Patients with depression display cytokine levels in serum and cerebrospinal fluid similar to patients with diffuse neurological symptoms without a defined diagnosis. Neuropsychiatr Dis Treat 12:817

26. Köhler O, Benros ME, Nordentoft M, Farkouh ME, lyengar RL, Mors O, Krogh $J$ (2014) Effect of anti-inflammatory treatment on depression, depressive symptoms, and adverse effects: a systematic review and meta-analysis of randomized clinical trials. JAMA Psychiatry 71(12):1381-1391

27. Raison CL, Rutherford RE, Woolwine BJ, Shuo C, Schettler P, Drake DF et al (2013) A randomized controlled trial of the tumor necrosis factor antagonist infliximab for treatment-resistant depression: the role of baseline inflammatory biomarkers. JAMA Psychiatry 70(1):31-41

28. Rudolf S, Greggersen W, Kahl KG, Hüppe M, Schweiger U (2014) Elevated IL6 levels in patients with atypical depression but not in patients with typical depression. Psychiatry Res 217(1-2):34-38

29. Woelfer M, Kasties V, Kahlfuss S, Walter M (2019) The role of depressive subtypes within the neuroinflammation hypothesis of major depressive disorder. Neuroscience 403:93-110

30. Pae CU, Tharwani H, Marks DM, Masand PS, Patkar AA (2009) Atypical depression. CNS drugs 23(12):1023-1037

31. Stewart JW, McGrath PJ, Fava M, Wisniewski SR, Zisook S, Cook I, Lesser I (2010) Do atypical features affect outcome in depressed outpatients treated with citalopram? Int J Neuropsychopharmacol 13(1):15-30

32. Bowlby, J. (1980). Attachment and loss: Vol. 3. Loss: Depression and sadness.

33. Matza LS, Revicki DA, Davidson JR, Stewart JW (2003) Depression with atypical features in the National Comorbidity Survey: classification, description, and consequences. Arch Gen Psychiatry 60(8):817-826

34. Danese A, Pariante CM, Caspi A, Taylor A, Poulton R (2007) Childhood maltreatment predicts adult inflammation in a life-course study. Proc Natl Acad Sci U S A 104(4):1319-1324

35. Park HS, Park JY, Yu R (2005) Relationship of obesity and visceral adiposity with serum concentrations of CRP, TNF- $a$ and IL-6. Diabetes Res Clin Pract 69(1):29-35

36. Tilg H, Moschen AR (2006) Adipocytokines: mediators linking adipose tissue, inflammation and immunity. Nat Rev Immunol 6(10):772

37. Lyndon B, Parker G, Morris G, Das P, Outhred T, Hamilton A et al (2017) Is atypical depression simply a typical depression with unusual symptoms? Aust NZJ Psychiatry 51(9):868-871

38. Montoya JG, Holmes TH, Anderson JN, Maecker HT, Rosenberg-Hasson $Y$ et al (2017) Cytokine signature associated with disease severity in chronic fatigue syndrome patients. Proc Natl Acad Sci U S A 114(34):E7150-E7158

39. Xin L-M, Chen L, Su Y-A, Yang F-D, Wang G, Fang Y-R et al (2019) Prevalence and clinical features of atypical depression among patients with major depressive disorder in China. J Affect Disord 246:285-289

40. Courtet P, Jaussent I, Genty C, Dupuy AM, Guillaume S, Ducasse D et al (2015) Increased CRP levels may be a trait marker of suicidal attempt. Eur Neuropsychopharmacol 25(10):1824-1831

41. Suchankova P, Holm G, Träskman-Bendz L, Brundin L, Ekman A (2013) The+ $1444 C>T$ polymorphism in the CRP gene: a study on personality traits and suicidal behaviour. Psychiatric genetics 23(2):70-76

42. Vargas HO, Nunes SOV, de Castro MP, Bortolasci CC, Barbosa DS, Morimoto HK et al (2013) Oxidative stress and lowered total antioxidant status are associated with a history of suicide attempts. J Affect Disord 150(3):923-930

\section{Publisher's Note}

Springer Nature remains neutral with regard to jurisdictional claims in published maps and institutional affiliations.

\section{Submit your manuscript to a SpringerOpen ${ }^{\circ}$ journal and benefit from:}

- Convenient online submission

- Rigorous peer review

- Open access: articles freely available online

- High visibility within the field

- Retaining the copyright to your article

Submit your next manuscript at $\boldsymbol{\nabla}$ springeropen.com 